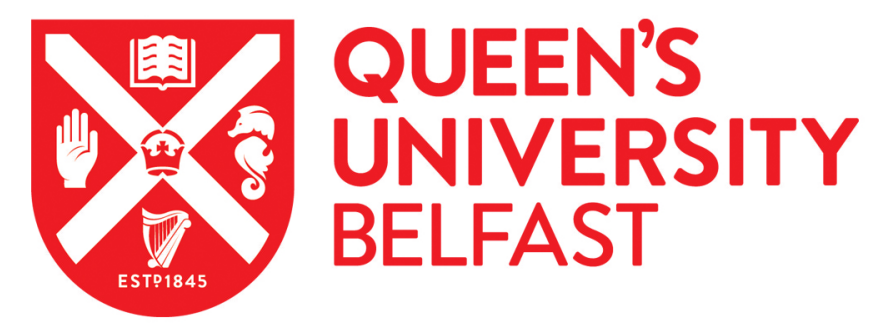

\title{
Osteopontin (OPN) Downregulatory Alkaloid (-)-Agelastatin A Prevents Muscle Damage in a Mouse Model of Duchenne Muscular Dystrophy
}

Madison Feng, López, S. M., Manaviazar, S., Watson, H. A., Hale, K. J., \& Nghiem, P. P. (2021, Mar 16).

Osteopontin (OPN) Downregulatory Alkaloid (-)-Agelastatin A Prevents Muscle Damage in a Mouse Model of Duchenne Muscular Dystrophy. ChemRxiv. https://doi.org/10.26434/chemrxiv.14210882v1

Document Version:

Other version

Queen's University Belfast - Research Portal:

Link to publication record in Queen's University Belfast Research Portal

Publisher rights

Copyright 2021 the authors.

This is an open access article published under a Creative Commons Attribution-NonCommercial-NoDerivs License

(https://creativecommons.org/licenses/by-nc-nd/4.0/), which permits distribution and reproduction for non-commercial purposes, provided the author and source are cited

\section{General rights}

Copyright for the publications made accessible via the Queen's University Belfast Research Portal is retained by the author(s) and / or other copyright owners and it is a condition of accessing these publications that users recognise and abide by the legal requirements associated with these rights.

Take down policy

The Research Portal is Queen's institutional repository that provides access to Queen's research output. Every effort has been made to ensure that content in the Research Portal does not infringe any person's rights, or applicable UK laws. If you discover content in the Research Portal that you believe breaches copyright or violates any law, please contact openaccess@qub.ac.uk. 


\title{
Osteopontin (OPN) Downregulatory Alkaloid (-)-Agelastatin A Prevents Muscle Damage in a Mouse Model of Duchenne Muscu- lar Dystrophy
}

\author{
Madison Feng, ${ }^{\dagger}$ Sara Mata López, ${ }^{\dagger}$ Soraya Manaviazar, ${ }^{\Uparrow}$ Hamish A. Watson, ${ }^{\circledR}$ Karl J. Hale, ${ }^{\Uparrow *}$ and \\ Peter P. Nghiem ${ }^{\dagger} *$ \\ ${ }^{\dagger}$ The Texas A\&M Institute for Neuroscience, the Department of Veterinary Integrative Sciences, the College of Veterinary \\ Medicine and Biomedical Sciences, Texas A \& M University, Bryan College Station, Texas TX 77843-4458, USA. \\ "The School of Chemistry and Chemical Engineering, Queen's University Belfast, Stranmillis Road, Belfast BT9 5AG, \\ Northern Ireland, United Kingdom.
}

KEYWORDS Osteopontin, $\beta$-catenin, (-)-agelastatin A, Duchenne muscular dystrophy (DMD), canine myoblasts, mdx mice

\begin{abstract}
Agelastatin A (AA) in 1,2-propanediol (3-deoxy-DL-glycerol) elicits a dose-dependent decrease in OPN mRNA expression in canine Duchenne Muscular Dystrophy (DMD) myoblasts at doses ranging from $0.01 \mathrm{nM}-30 \mathrm{nM}$. When intraperitoneally administered in the same vehicle to mdx mice at $2.5 \mathrm{mg} / \mathrm{kg} /$ day for two weeks, and at $1.5 \mathrm{mg} / \mathrm{kg} / \mathrm{day}$ twice-weekly for two weeks, (-)-AA brings about a significant decrease in exercise-induced muscle damage through its attenuation of OPN expression. Because (-)-AA is known to downregulate OPN, this study confirms that the use of small molecule OPN downregulatory drugs can beneficially modify the phenotype in DMD animal models and potentially affected boys
\end{abstract}

Duchenne muscular dystrophy (DMD) is a devastating, monogenic, muscle-wasting disease caused by a loss of fulllength dystrophin protein from within striated muscle; ${ }^{1-7}$ an event which disrupts the normal structural integrity and proper functioning of the costameric dystrophin-glycoprotein complexes that link the sarcolemma to the myofibrils. ${ }^{1-4}$ Most cases of DMD are attributable to specific mutations in the dystrophin gene, which subsequently cause a shift in the open reading frame of the dystrophin mRNA that is produced, ${ }^{8-12}$ with some $60-70 \%$ of mutations involving the deletion of an exon from a key "hot-spot" region around exons 44-53. .7 $^{5-7}$

The primary effect of losing full-length functional dystrophin from striated muscle is the creation of an extremely weak, highly disorganized, costameric cytoskeleton ${ }^{3,4}$ which is unable to support the normal repeated muscle stretching and contracting that occurs during exercise-induced damage. ${ }^{13}$ These events then bring about spontaneous cellular apoptosis within the affected muscle tissue, accompanied by muscle degeneration. The necrotic injury that ensues then promotes widespread muscle inflammation and fibrosis, and causes the dystrophic muscle cells to transform into fibro-adipocytes, ${ }^{14}$ which then promote fat infiltration into the skeletal muscle and allied fibrosis. Together, these events cause severe muscle wasting and weakness; events which typically induce paralysis before the age of 12 , and death by the age of 30 , frequently from attendant cardiac or respiratory failure.

There is remarkable variability in the extent to which many individuals are affected by DMD, with the first debilitating signs of the disease typically manifesting themselves between the ages of 2 to 5 . Most of the phenotypic variability is associated with the type of gene mutation that has arisen. Either inframe or out-of-frame, with the former leading to the much milder Becker MD syndrome, in which some truncated functional dystrophins can still be found; and the latter leading to the more severe DMD disease, where dystrophin is absent.

That said, there are many external modifiers that can dramatically accelerate DMD progression. ${ }^{15}$ One of these is osteopontin (OPN); also known as secreted phosphoprotein 1 (SPP1), ${ }^{16}$ which can markedly exacerbate the amount of muscle damage, inflammation, and fibrosis that can occur, ${ }^{17-20}$ particularly when it is chronically-overexpressed within DMD muscle, as happens, when there is repeated mechanicallyinduced muscle injury.

While it is possible to delay the progressive muscle weakness, attendant loss of ambulation, and generally declining motor function with the aid of corticosteroid drugs (e.g. prednisolone or deflazacort) (Fig. 1), ${ }^{21}$ these benefits are only temporary. Steroidal drugs also often elicit many undesired sideeffects such as immunosuppression, neuropsychiatic deficits, osteoporosis, slow wound healing, metabolic derangements, growth retardation in children, amongst others.

One advance in the field of DMD drug design has been the introduction of Ataluren (Fig. 1), ${ }^{22}$ a simple aromatic heterocycle that very effectively corrects 'nonsense' mutation dystrophinopathy by a mechanism that has yet to be defined. It has an acceptable toxicity profile, and has already demonstrated significant clinical benefit when it is orally administered to DMD patients with a 'nonsense' mutation at a dose of 
Main Corticosteroid Drugs Used For Treating DMD
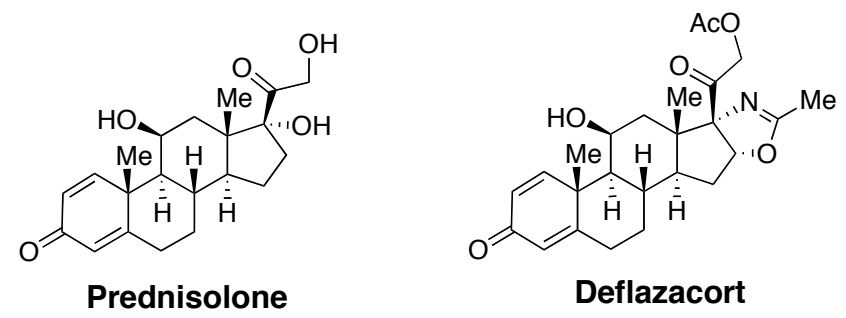

Ataluren: Treats 'Nonesense' Mutations in the Dystrophin Gene

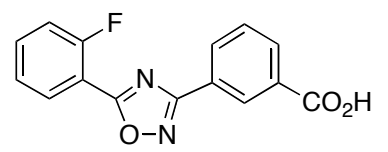

Ataluren

Figure 1. Representative corticosteroid and 'nonsense' mutationskipping drugs used to treat DMD.

$40 \mathrm{mg} / \mathrm{kg} /$ day. However, it is not totally without toxicity with typical side-effects including nausea and vomiting, severe abdominal discomfort, in some cases high tri-glyceride levels, and urinary incontinence to focus on a few.

While other technologies such as gene replacement therapy ${ }^{23}$ hold quite considerable promise, the long-term efficacy of these approaches has yet to be established, most especially for patients with advanced disease, including significant fibrosis.

Therefore, there is quite considerable effort presently underway in developing new and much more effective DMD drug treatments that will act on a range of alternate drug targets and be affordable. Because upregulated $\beta$-catenin ${ }^{24}$ and OPN expression ${ }^{17}$ both significantly promote muscle necrosis, inflammation and worsen the overall degree of fibrosis in DMD, our approach has been to delineate whether potent small molecule antagonists of $\beta$-catenin and OPN expression will be of potential value for preventing much of the very severe muscle damage and wasting that occurs in mouse models of DMD (mdx).

However, as a counterpoint, OPN does have proregenerative effects in muscle tissue: it collectively promoting myoblast proliferation $^{25}$ and stimulating the AKT (protein kinase B) pathway, ${ }^{26}$ which both promote muscle growth. $\beta$ Catenin can likewise play a substantive role in muscle regeneration. The pharmacological blockade of both proteins would thus require a very careful and delicate balance to be struck between allowing the pro-regenerative attributes to be retained, and the pro-inflammatory/pro-fibrotic properties to be significantly curtailed.

(-)-Agelastatin A [(-)-AA] (Fig. 2) is a naturally-occurring oroidin alkaloid of marine sponge origin ${ }^{27,28}$ that can potently downregulate upregulated $\beta$-catenin and OPN levels within metastatic rat mammary Rama 37 OPN pBK-CMV and human breast carcinoma MDA-MB435 cells. ${ }^{28}$ It does so at

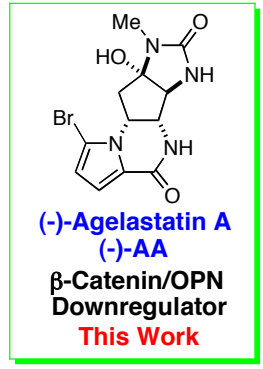

Figure 2. (-)-Agelastatin A: a novel oroidin alkaloid of marine sponge origin ${ }^{27}$ that has the ability to potently downregulate $\beta$ catenin and OPN expression. ${ }^{28}$

concentrations of $10 \mathrm{nM}$ to $1 \mu \mathrm{M},{ }^{28}$ in a manner that correlates with inhibition of cancer cell growth and metastasis. ${ }^{27-29} \mathrm{Be}-$ cause of its profound downregulatory effects on $\beta$-catenin and OPN expression, its good antitumor effects against xenografted human tumors in nude mice, ${ }^{27-29}$ and its accessibility in substantial quantity via total chemical synthesis, ${ }^{29}$ we decided to investigate the potential of (-)-AA for preventing exercise-induced muscle damage in an $\mathrm{mdx}$ mouse model of DMD. Concurrently, we also wished to investigate the effects of (-)-AA on the expression of OPN in the muscle tissues of treated mdx mice. Herein, we report the results of this preliminary enquiry.

Initially, we evaluated the biological impact of (-)-AA on normal-genotyped and dystrophin-deficient myoblasts extracted from normal and golden retriever muscular dystrophy (GRMD) dogs. ${ }^{30}$ This involved us treating such cells with (-)AA dissolved in 1,2-propanediol (3-deoxy-DL-glycerol) over a range of drug concentrations from $0.01-1000 \mathrm{nM}$ (for timelines up to $72 \mathrm{~h}$ ), and then analyzing their mRNA for OPN expression. Although we did observe a reduction in OPN mRNA in normal dog myoblasts, the response was not dosedependent (Fig. 3A). However, a dose-dependent decrease in OPN mRNA was observed in canine DMD myoblasts after ()-AA treatment at concentrations from 0.01-30 nM (Fig. 3B). In both cell settings, we also observed a dose-dependent cell detachment at doses $\geq 100 \mathrm{nM}$ (not shown). We further treated cells with (-)-AA dissolved in DMSO. In the latter experiments, we noted significant cell detachment in both placebo (DMSO only) and (-)-AA-treated cells (Supplemental Figure $1)$, suggesting that (-)-AA is more toxic to myoblasts when it is administered in DMSO than when it is delivered in 1,2propanediol. In light of this, we decided to use 1,2-propanediol (3-deoxy-DL-glycerol) as the vehicle for (-)-AA administration in all our subsequent in vivo studies.

In this evaluation, one group of $\mathrm{mdx}$ mice ( 7 weeks old) was treated with placebo (saline), and the other was administered $2.5 \mathrm{mg} / \mathrm{kg} /$ day of (-)-AA dissolved in 1,2-propanediol via intraperitoneal injection for 14 days. One mouse in each of these groups unfortunately died due to the physical complications that arose from the repeated intraperitoneal injections. However, both fatalities were totally unrelated to the (-)-AA itself. The remaining mice completed the drug testing without becoming moribund or displaying any other signs of toxicity ( $n=6$ in the (-)-AA treatment group, and $n=9$ in the placebo group). We measured the body weight of each group 

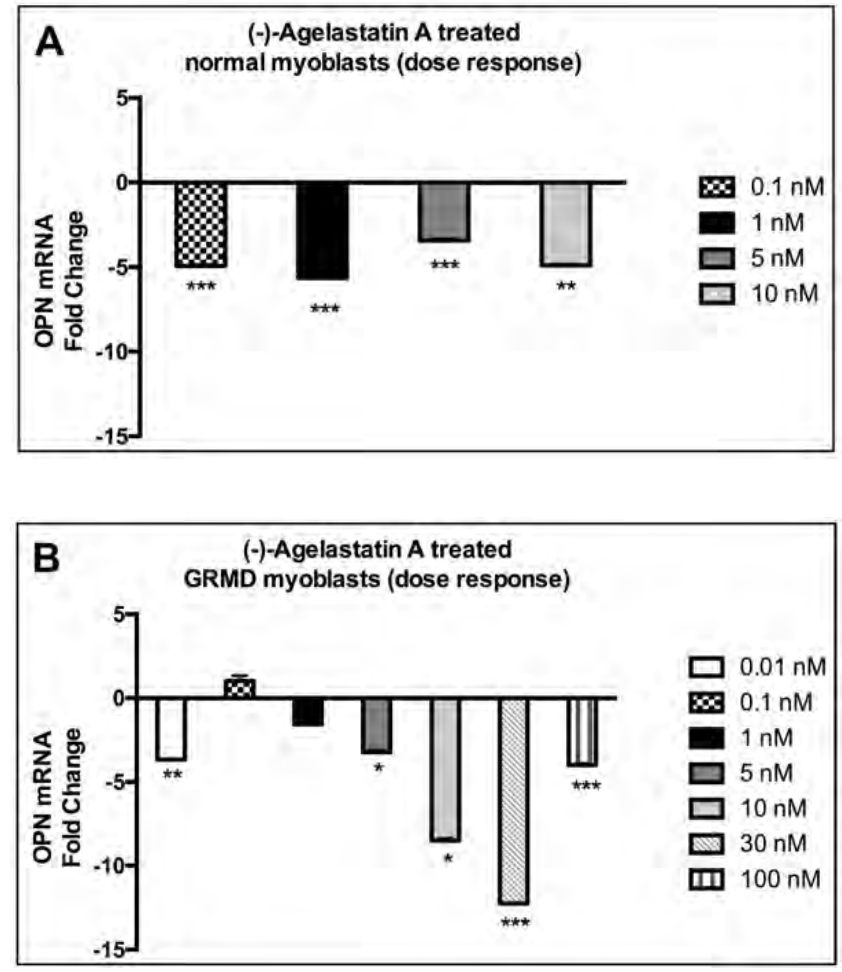

Figure 3. (-)-Agelastatin A administered in 1,2-propanediol decreased OPN mRNA expression in normal and GRMD myoblasts. Quantitative real-time PCR was performed to quantify OPN mRNA. Expression of OPN was determined as a fold change of 1 x PBS control-treated cells. HPRT1 was used as an internal control for saline and (-)-AA-treated cells. A pair-wise fixed reallocation randomization test was performed to determine fold change. A) Normal genotypes myoblasts were treated with a dose range from 0.1-10 $\mathrm{nM}$. There were significant reductions in OPN expression, but these were not dose-dependent. B) GRMD myoblasts showed a dose-dependent decrease in OPN mRNA (dose range from 0.01-100 nM). It should be noted that $1 \mathrm{mM} \mathrm{(-)-}$ AA resulted in significant cell death and OPN could not be measured as a result. $*=\mathrm{p}<0.05 ; * *=\mathrm{p}<0.01 ; * * *=\mathrm{p}<0.001$

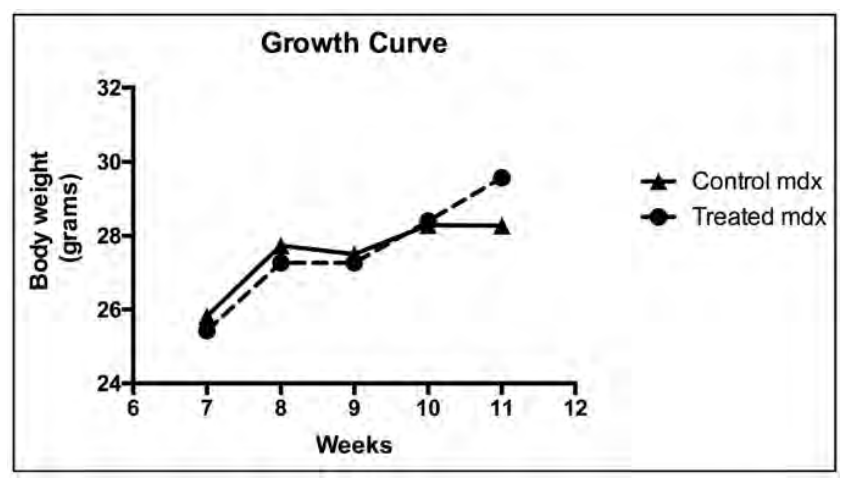

Figure 4. (-)-Agelastatin A (treated) mdx mice had a similar growth curve compared to saline (control)-treated mdx mice. All mice were age-matched males and weighed weekly. No significant differences were observed between groups for each week. $\mathrm{N}=6-9$ per group.

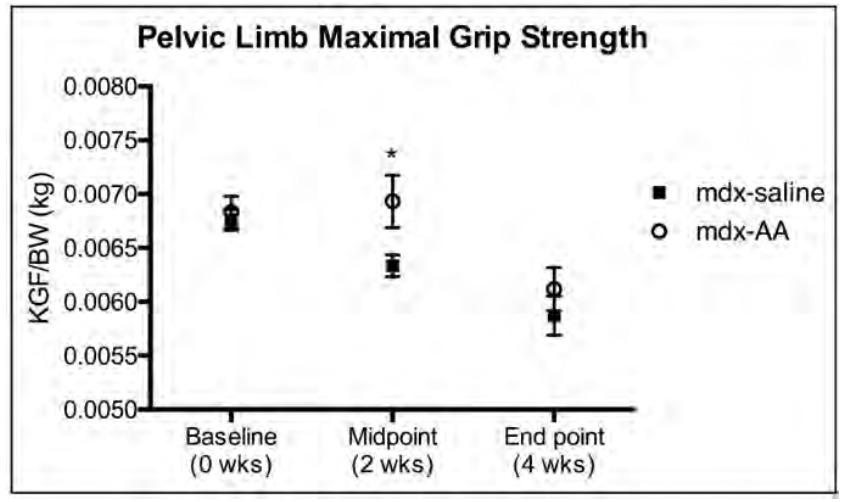

Figure 5. (-)-Agelastatin A improved pelvic limb grip strength in mdx mice. Mdx mice ( 7 week old) were given $2.5 \mathrm{mg} / \mathrm{kg} /$ day of (-)-AA in 1,2-propanediol intraperitoneally from baseline to mid-point ( 2 weeks duration) and then $1.5 \mathrm{mg} / \mathrm{kg} /$ day twice per week from mid-point to end-point ( 3 weeks total treatment). Pelvic limb grip strength was improved with the $2.5 \mathrm{mg} / \mathrm{kg} /$ day dosage compared to the $1.5 \mathrm{mg} / \mathrm{kg}$ /day twice a week regime. There were no significant differences in thoracic limb grip strength between (-)-AA- and saline-treated mdx mice at either dosage. $\mathrm{Kg}=$ kilograms; KGF = kilograms of force; $\mathrm{BW}=$ body weight; $*=\mathrm{p}<$ 0.05 .

throughout the study and no major differences in growth pattern were apparent (Fig. 4). Significantly, though, we did observe a modest increase in pelvic limb grip strength in $\mathrm{mdx}$ mice following two weeks of (-)-AA treatment at 2.5 $\mathrm{mg} / \mathrm{kg} / \mathrm{day}$, when these animals were compared with the placebo mdx mice (Fig. 5). Having observed phenotypic improvement at $2.5 \mathrm{mg} / \mathrm{kg} /$ day over 14 days, we next decided to considerably reduce the (-)-AA dosage to $1.5 \mathrm{mg} / \mathrm{kg} /$ day twice weekly for an additional two weeks, to see if this phenotypic improvement could be maintained at this much lower dosage. When the latter assessment was complete, we again performed grip strength measurements, but now, we did not see any statistical improvement relative to the placebo-treated mdx mice. The data that we have gathered to date very strongly suggests that long-term therapy with (-)-AA at $2.0-2.5 \mathrm{mg} / \mathrm{kg} /$ day for several months would produce a major phenotypical improvement in mdx mice.

At the end of this efficacy trial, histopathological analyses were conducted of various muscle tissues taken from the (-)AA-treated mdx mice. Because OPN is typically upregulated in necrotic myofibers, we initially analyzed (-)-AA-treated mdx muscle tissue for necrotic areas. The total number of such areas was greatly reduced in (-)-AA-treated mdx quadriceps muscle (Fig. $6 \mathrm{~A}+\mathrm{C}$ ) when compared to the same muscle from placebo-treated mdx mice. We further analyzed other (-)-AAtreated muscles for necrosis, but did not observe any statistically relevant reduction in the amount of necrosis. This is aligned with each muscle responding differently to both dystrophin deficiency and to various genetic therapies. ${ }^{23}$

In an effort to confirm that the postulated $\beta$-catenin/OPN downregulatory mechanism was indeed responsible for the observed anti-DMD therapeutic effects in our (-)-AA-treated mdx mice, we measured the final levels of downstream OPN expression in our harvested quadriceps muscle tissues, via 

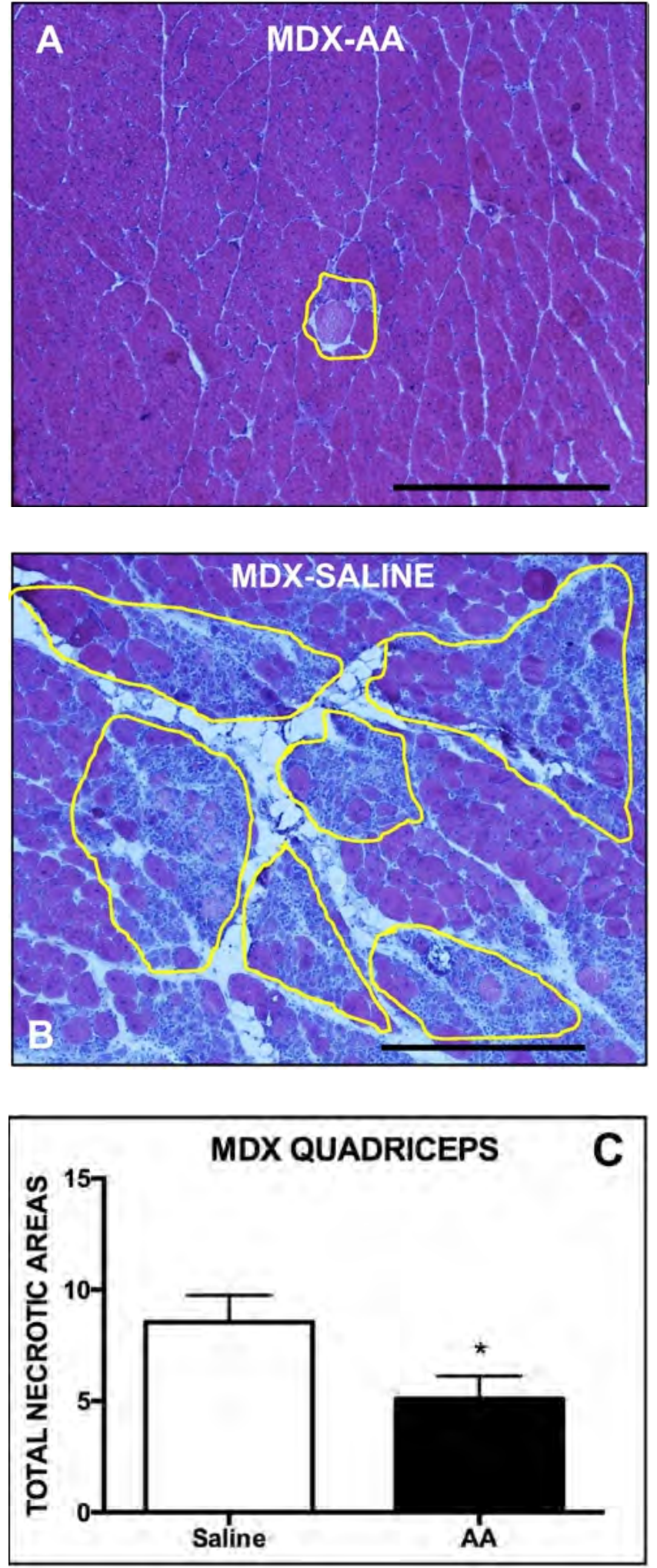

Figure 6. (-)-Agelastatin A (AA) treatment reduced necrotic areas in treadmill-exercised mdx muscle. Saline- and (-)-AAtreated mdx mice were treadmill exercised at $12 \mathrm{~meters} / \mathrm{min}$ for 30 min twice per week to induce muscle damage. A) (-)-AAtreated mdx quadriceps muscle showed reduced necrotic areas. It should be noted, however, that necrosis was still present, but less so than B) saline-treated mdx quadriceps. The encapsulated yellow areas outline small and large necrotic regions of muscle. Marker $=500 \mathrm{mM}$. C) Total necrotic areas quantified.
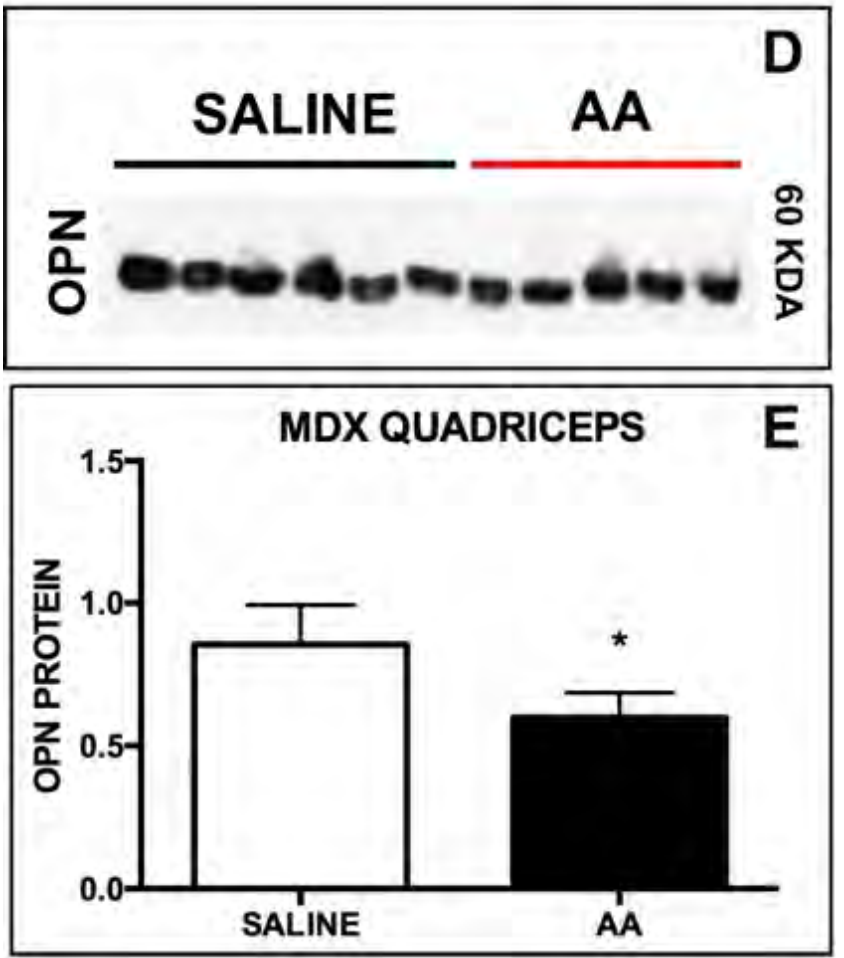

Figure 6 continued. (-)-Agelastatin A (AA) treatment reduced OPN expression in treadmill-exercised mdx muscle. D) OPN protein (normalized to total protein on PVDF membrane (not shown) depicted in western blot in saline vs (-)-AA treated $\mathrm{mdx}$ mice. E) OPN protein quantified; $*=p<0.05$.

western blot, and we noted a reduction of approximately $20 \%$ in the OPN protein level 4 weeks after beginning (-)-AAtreatment according to the schedule: $2.5 \mathrm{mg} / \mathrm{kg} / \mathrm{day}$ for 14 days and $1.5 \mathrm{mg} / \mathrm{kg} /$ day twice weekly for a further 14 days (Fig. 6. D+E).

Undoubtedly, this reduction in the (-)-AA dosage and the frequency of administration, over the final two weeks of the study, almost certainly contributed to the more modest lowering $(20 \%)$ of OPN expression ultimately seen; a fact endorsed by the lower grip strength measurements that were also finally recorded at study end. Nonetheless, it is noteworthy that a substantial reduction in OPN expression was still seen with a (-)-AA dosage as low as $1.5 \mathrm{mg} / \mathrm{kg} /$ day administered just twice weekly. The collective data that we have gathered thus confirms that even at quite low, sub-optimal, dosages, (-)-AA is still a potent in vivo inhibitor of OPN, and given our previous work ${ }^{27,29}$ in a range of animal and human cell lines, this property is undoubtedly due to the powerful downregulatory effects of (-)-AA on $\beta$-catenin expression, ${ }^{28}$ which reduces the amount of $\beta$-catenin/TCF4 (T-Cell Factor 4)-mediated OPN gene transcription that can occur from the OPN promoter. ${ }^{28,16}$

Finally, our preliminary toxicological studies had shown that AA was safe and well-tolerated in wild-type mice at dosages of $4 \mathrm{mg} / \mathrm{kg} / \mathrm{day}$. Given this, we initially assessed AA at this higher dosage of $4 \mathrm{mg} / \mathrm{kg} /$ day in three $\mathrm{mdx}$ mice and found that two of them became moribund. Indeed, one of these two mice died, not long after, and the other needed to be humanely euthanized due to neurological deficits. These studies suggest that some mdx mice are either more sensitive to the 
effects of AA, or they have a different pharmacokinetic or absorptive profile, leading to toxic levels of AA at this dosage.

So to conclude, in this investigation we have documented, for the first time, the downstream effects of treating dystrophin deficiency with (-)-AA, in both canine DMD myoblasts, and in an mdx mouse model of DMD. Osteopontin/SPP1, a downstream transcriptional target of the $\beta$-catenin/TCF4 interaction, ${ }^{16,28}$ is well known to be significantly overexpressed in $\mathrm{DMD}^{17-20}$ and its animal models, and recent studies have pointed to this pro-inflammatory/fibrotic cytokine potentially providing a very good therapeutic drug target for the alleviation of DMD; the present pharmacological testing now confirms this fact. Other studies ${ }^{25}$ have also revealed a critical role for OPN in promoting myoblast/muscle proliferation, regeneration, and growth. Therefore, this ability of (-)-AA ${ }^{28,29}$ to pharmacologically manipulate the expression of OPN, in a way where its injurious pro-inflammatory/fibrotic effects can be diminished, and its beneficial, pro-regenerative, properties can be maintained, is of substantive interest. In this regard, we detected a significant reduction in OPN mRNA expression in canine DMD myoblasts after treatment with (-)-AA, and a similar reduction in OPN expression was also seen in $\mathrm{mdx}$ mice at a low non-toxic dosage. We therefore believe that the noticeable improvements in grip strength and the significant reduction in muscle necrosis that occurs after just 14 days of ()-AA treatment will be more than capable of being optimized through a careful study of (-)-AA dosing in larger mdx mouse populations. Future studies will address this issue and evaluate (-)-AA in canine models of DMD, now that this improved new administration vehicle of 1,2-propanediol (3-deoxy-DLglycerol) has been identified for administering (-)-AA safely and without significant cytotoxicity.

\section{EXPERIMENTAL PROCEDURES}

Materials. The (-)-agelastatin A (AA) used here was synthesized according to experimental procedures detailed in our previously published route. $^{29}$

Animals. All animals were cared for according to the National Research Council's Guide for the Care and Use of Laboratory Animals. Animal studies were approved by the Institute for Animal Care and Use Committee at Texas A\&M University under protocols 2018-0182 and 2019-0393. There were 10 and $7 \mathrm{mdx}$ mice per group (placebo and (-)-AA-treated, respectively) and 3 mdx mice for the dose escalation study.

(-)-AA Dilution. (-)-Agelestatin-A was initially diluted with dimethyl sulfoxide and assessed in cell culture. In all subsequent cell culture studies, (-)-AA was diluted in propylene glycol to make concentrations of $0.01,0.1,1,5,10,30,100$ nanomols (nM) and $1,10,30$, and 100 micromols $(\mu \mathrm{M})$. For in vivo studies, AA was diluted with propylene glycol to make 1.5 to $4 \mathrm{mg} / \mathrm{kg}$ of body weight (BW) dilutions.

Cell Culture. Muscle biopsies and myoblast isolation were performed as previously described. ${ }^{23 \mathrm{~d}}$ Briefly, muscle was surgically biopsied under aseptic technique from a pelvic limb muscle of a normal and canine DMD dog. ${ }^{30}$ Myoblasts were then isolated with a pre-plate technique and cryopreserved until analysis. For cell treatments, myoblasts were plated in flasks and then transferred to collagen-coated 6,12 , and 24 well plates with $1-5 \times 10^{5}$ cells per well in complete growth/proliferation medium. Myoblasts were allowed to attach to the collagen plate and proliferate until approximately $70 \%$ confluency.

Cell Treatments. Myoblasts were treated for $24 \mathrm{~h}, 48 \mathrm{~h}$, and $72 \mathrm{~h}$ with either placebo (diluted in DMSO or 1,2-propylene glycol) or (-)-AA. Images were taken with a light microscope before treatment and every $24 \mathrm{~h}$. After treatment, cells were harvested for RNA or protein, as previously described.

(-)-AA Mdx Studies. Mdx mice were purchased from Jackson Laboratories. Mice were 6 weeks of age upon delivery and then acclimatized to the running treadmill (Columbus Instruments) and grip strength meters for 1 week. Mdx mice were run on the exercise treadmill twice a week, $30 \mathrm{~min}$ each session, for the duration of this study. The grip strengths of the thoracic and pelvic limbs were measured daily for 5 consecutive days at the beginning of the second week of dosing and the fourth week of dosing. Mice were injected intraperitoneally every $24 \mathrm{~h}$ for the first two weeks of the study at $2.5 \mathrm{mg} / \mathrm{kg} /$ day of (-)-AA and then $1.5 \mathrm{mg} / \mathrm{kg} / \mathrm{day}$ twice weekly for the final two weeks (for a total four week regime). $24 \mathrm{~h}$ after the very last (-)-AA treatment, the mice were humanely euthanized by carbon dioxide inhalation and their muscle tissue was harvested for microscopic and protein analyses.

Microscopic Analysis. A light microscope and cellular camera were used to take images of cells every $24 \mathrm{~h}$ to confirm cell attachment. For muscle tissue, cryosectioned tissue was analyzed, as previously described. ${ }^{31}$ Briefly, muscle tissue was analyzed at $4 \mathrm{X}$ magnification to identify necrotic areas. Once identified, necrotic areas were then divided into small or large necrotic areas, with differentiation between the two being $<=3$ necrotic fibers (small) or $>3$ necrotic fibers (large). The sum of small and large necrotic areas equaled to the total necrosis. Total necrosis was then compared between placebo and (-)-AA-treated muscles. Multiple muscles (vastus lateralis, gastrocnemius, diaphragm) were analyzed per mouse.

RNA and Protein Analysis. Total RNA was extracted from cell culture with Tripure, and its quality and quantity were determined with a Bioanalyzer, as previously described. ${ }^{32}$ Complementary DNA was generated by reverse transcription. We analyzed (-)AA-treated cultures for OPN mRNA expression using SYBR green assays. Primers for OPN and the internal control, HPRT1, as well as quantitative, real-time PCR parameters can be found in a previously published study. ${ }^{32}$ Total protein was extracted and quantified from cell culture and muscle tissue. Western blots were performed with a wet transfer, as previously described. ${ }^{33}$

\section{ASSOCIATED CONTENT}

\section{Supporting Information}

A single jpg. file is supplied containing a Supplemental Figure 1 depicting how (-)-AA in DMSO causes significant cell death in myoblasts. This Supporting Information is available free of charge on the ACS Publications website.

\section{AUTHOR INFORMATION}

\section{Corresponding Authors}

pnghiem@tamu.edu

Tel: +1(979)-862-918.

k.j.hale@qub.ac.uk

Tel: +44-(0)289097-5525. 


\section{Author Contributions}

The biological experiments reported here were conducted by the Texas A \& $\mathrm{M}$ team, and the chemical synthesis work on (-)-AA was done by the QUB team. The final manuscript was written through contributions of all the authors. All authors have given their approval to this final version of the manuscript

\section{Funding Sources}

The biological studies reported here were supported by a starter grant to PPN. The chemical synthesis work was supported by a DfE studentship to HAW, and an ACS Publications Grant to $\mathrm{KJH} / \mathrm{SM}$.

\section{Conflicts of Interest}

Peter P. Nghiem is a paid scientific consultant for Agada Biosciences.

\section{ACKNOWLEDGMENT}

We thank Cynthia Balog-Alvarez for biological technical advice and Amanda K. Bettis and Dr. Ryan Massopust for their animalrelated studies.

\section{ABBREVIATIONS}

(-)-AA, (-)-agelastatin A; DMD, Duchenne muscular dystrophy; mdx, murine-X-linked muscular dystrophy; OPN, osteopontin; SPP1, secreted phosphoprotein 1; AKT, protein kinase B; TCF4, T Cell Factor 4; DMSO, dimethyl sulfoxide.

\section{REFERENCES}

(1) (a) Ervasti, J. M.; Campbell, K. P. Membrane organization of the dytrophin-glycoprotein complex. Cell 1991, 66, 1121-1131.

(2) Michele, D. E.; Campbell, K. P. Dystrophin-Glycoprotein Complex: post translational processing and and dystroglycan function. J. Biol. Chem. 2003, 278, 15457-15460.

(3) Ervasti, J. M. Structure and function of the DystrophinGlycoprotein Complex. Madame Curie Bioscience Database. Austin (TX); Landes Bioscience; 2000-2013. NCBI Bookshelf. https://www.ncbi.nlm.nih.gov/books/NBK6193/ (accessed 2020-0911)

(4) Peter, A. K.; Cheng, H.; Ross, R.S. Knowlton, K. U.; and Chen, J. The costamere bridges sarcomeres to the sarcolemma in striated muscle. Prog. Pediatr Cardiol., 2011, 31, 83-88.

(5) Monaco, A. P. Neve, R. L.; Colletti-Feener, C.; Berteleson, C. J.; Kurnit, D. M.; Kinkel, L. M. Isolation of candidate cDNAs for portions of the Duchenne muscular dystrophy gene. Nature 1986, $323,646-650$.

(6) Hoffman, E. P.; Brown, R. H.; Kunkel, L. M. Dystrophin: the protein product of the Duchenne muscular dystrophy locus. Cell 1987, 51, 919-928.

(7) O'Brien, K. J.; Kinkel, L. M. Dystrophin and muscular dystrophy. Past, present, and future. Mol. Genet. Metab. 2001, 74, 75-88.

(8) Blake. D. J.; Weir A. Newey, S. E. ; Davies, K. E. Function and genetics of dystrophin and dystrophin-related proteins in muscle. Physiol. Rev. 2002, 82. 291-329.

(9) Doorenweerd, N.; Mahfouz, A; van Putten, M.; Kaliyaperumal, R.; t'Hoen, P. A. C.; Hendriksen, J. G. M.; Aartsma-Rus, A. M.; Niks, E. H.; Reinders, M. J. T.; Kan, H. E.; Leieveldt, B. P. F. Timing and localization of human dystrophin isoform expression provides insights into the cognitive phenotype of Duchenne muscular dystrophy. Sci. Rep. 2017, 7, 12575.

(10) Upadhyay, V.; Bandi, S.; Pamja, S.; Saba, L.; Mallela, K. M. G. Tissue-specificity of dystrophin-actin interactions: Isofirm-specific thermodynamic stability and actin-binding function of tandem calponin-homology domains. ACS Omega 2020, 5, 2159-2168
(11) Culligan, K. G.; Mackey, A. J.; Finn, D. M.; Maguire, P. B. Ohlendieck, K. Role of dystrophin isoforms and associated proteins in muscular dystrophy. Int. J. Mol. Med. 1998, 2, 639-687

(12) Nudel, U. Zuk, D.; Einat, P.; Zeelon, E.; Levy, Z.; Neuman, S.; Yaffe, D. Duchenne muscular dystrophy gene product is not identical in muscle and brain. Nature 1989, 337, 76-78

(13) Petrof, B. J.; Shrager, J. B.; Stedman, H. H.; Kelly, A. M.; Sweeney, H. L. Dystrophin protects the sarcolemma from stresses developed during muscle contraction. Proc. Natl. Acad. Sci. USA 1993, 90, 3710-3714

(14) Uezumi, A.; Ito, T.; Morikawa, D.; Shimizu, N.; Yoneda, T.; Segawa, M.; Yamaguchi, M.; Ogawa, R.; Matev, M. M.; MiyagoeSuzuki; Takeda, S.; Tsujikawa, K.; Tsuchida, K.; Yamamoto, H.; Fukada, S. Fibrosis and adipogenesis originate from a common mesenchymal progenitor in skeletal muscle. J. Cell. Sci. 2011, 124, $3654-$ 3664.

(15) Vo, A. H.; McNally, E. M. Modifier genes and their effect on Duchenne muscular dystrophy. Curr. Opin. Neurol. 2015, 28, 528534

(16) Denhardt, D. T.; Guo, X. Osteopontin: a protein with diverse functions. FASEB J. 1993, 7, 1475-1482.

(17) Vetrone, S. A.; Montecino-Rodriguez, E.; Kudyrashova, E.; Kramerova, I.; Hoffman, E. P.; Liu, S. D.; Micell, M. C.; Spencer, M. J. Osteopontin promotes fibrosis in dystrophic mouse muscle by modulating immune cell subsets and intramuscular TGF- $\beta$. J. Clin. Invest. 2009, 119, 1583-1594.

(18) Capote, J.; Kramerova, I.; Martinez, L.; Vetrone, S.; Barton, E. R.; Sweeney, H. L.; Miceli, M. C.; Spencer, M. J. Osteopontin ablation ameliorates muscular dystrophy by shifting macrophages to a pro-regenerative phenotype. J. Cell Biol. 2016, 213, 275-288.

(19) Uaesoontrachoon, K.; Wasgewatte Wijesinghe, D. K.; Mackie, E. J. Pagel, C. N. Osteopontin deficiency delays inflammatory infiltration and the onset of muscle regeneration in a mouse model of muscle injury. Disease Models and Mechanisms 2013, 6, 197-205.

(20) (a) Many, G. M.; Yokosaki, Y.; Uaesoontrachoon, K.; Nghiem P. P.; Bello, L.; Dadgar, S.; Yin, Y.; Dansker, J. M.; Cohen H. B.; Kornegay, J. M.; Bamman M. M.; Mosser, D. M.; Nagaraju, K.; Hoffman E. P. OPN- $\alpha$ induces muscle inflammation by increasing recruitment and activation of pro-inflammatory macrophages. Exp. Physiol. 2016, 101, 1285-1300. (b) Pegoraro, E.; Hoffman, E. P.; Piva, L.; Gavassini, B. F.; Cagnin, S.; Ermani, M.; Bello, L.; Soraru, G.; Pacchioni, B.; Bonifati, M. D.; Lanfranchi, G.; Angelini, C.; Kesan, A.; Lee, I.; Gordish-Dressman, H.; Devaney, J. M.; McDonald, C. M. SPP1 genotype is a determinant of disease severity in Duchenne muscular dystrophy. Neurology 2011, 76, 219-226.

(21) McDonald, C. M.; Sajeev, G.; Yao, Z.; McDonnell, E.; Elfring, G.; Douza, M.; Peltz, S. W.; Darras, B. T.; Shieh, P. B.; Cox, D. A.; Landry, J.; Signorovitch, J. Deflazacort vs prednisone treatment for Duchenne muscular dystrophy: A meta-analysis of disease progression rates in recent multicenter clinical trials. Muscle \& Nerve 2019, 61, 26-35.

(22) Bushby, K.; Finkel, R.; Wong, B.; Barohn, R.; Campbell, C.; Comi, G. P.; Connolly, A. M..; Day, J. W. ; Flanigan, K. M.; Goemans, N.; Jones, K. J.; Mercuri, E.; Quinlivan, R.; Renfroe, J. B.; Russman, B.; Ryan, M. M.; Tulinius, M.; Voit, T.; Moore, S. A.; Sweeney, H. L.; Abresch, R T.; Coleman, K. L.; Eagle, M.; Florence. J.; Gappmaier, E.; Glanzman, A. M.; Henrickson, E.; Barth, J.; ELfring, G. L.; Reha, A.; Spiegel, R. J.; O’Donnell, M. W.; Peltz, S. W.; McDonald, C. M. Ataluren treatment of patients with nonsense mutation dystrophinopathy. Muscle Nerve 2014, 50, 477-487.

(23) (a) Nghiem P. P.; Kornegay J. N. Gene therapies in canine models for Duchenne muscular dystrophy. Hum. Genet. 2019, 138, 483-489. (b) Hotta, A. Genome editing gene therapy for Duchenne muscular dystrophy. J. Neuromusc. Dis. 2015, 2, 343-355. (bc) Sienkiewicz, D.; Kulak, W.; Okurowska-Zawada, B.; Paszko-Patej, G.; Kawnik, K. Duchenne muscular dystrophy: current cell therapies. Ther. Adv. Neurol. Disord. 2015, 8, 166-177. (d) Mata López, S.; Balog-Alvarez, C.; Vitha, S.; Bettis, A. K.; Canessa E. H.; Kornegay J. N.; Nghiem P. P. Challenges associated with homologous directed repair using CRISPR-Cas9 and TALEN to edit the DMD genetic 
mutation in canine Duchenne muscular dystrophy. PLOS One. 2020 Jan 21, 15(1):e0228072.

(24) (a) Trensz, F,; Haroun, S.; Cloutier, A.; Richter, M. V.; Grenier, G. A muscle resident cell population promotes fibrosis in hindlimb skeletal muscles of $\mathrm{mdx}$ mice through the Wnt canonical pathway. Am. J. Physiol. Cell Physiol. 2010, 299, C939-C947. (b) Biressi, S.; Miyabara, E. H.; Gopinath, S. D.; Carlig, P. M. M.; Rando, T. A. A Wnt-TGF $\beta 2$ axis induces a fibrogenic program in muscle stem cells from dystrophic mice. Sci. Transl. Med. 2014, 6, 267 ra176.

(25) Uaesoontrachoon, K.; Yoo, H. J.; Tudor, E. M.; Pike, R. N.; Mackie E. J.; Pagel, C. N. Osteopontin and skeletal muscle myoblasts: association with muscle regeneration and regulation of myoblast function in vitro. Int. J. Biochem. Cell Biol. 2008, 40, 2303-2314.

(26) Nghiem, P. P.; Kornegay, J. N.; Uaesoontrachoon, K.; Bello, L.; Yin, Y.; Kesari, A.; Mittal, P.; Schatzberg, S. J.; Many G. M.; Lee N. H.; Hoffman E. P. Osteopontin is linked with AKT, FoxO1, and myostatin in skeletal muscle cells. Muscle Nerve 2017 56, 1119-1127.

(27) (a) D'Ambrosio, M.; Guerriero, A.; Debitus, C.; Ribes, O.; Pusset, J.; Leroy, S.; Pietra, F. Agelastatin A, a new skeleton cytotoxic alkaloid of the oroidin family. Isolation from the axinellid sponge Agelas dendromorpha of the coral sea. J. Chem. Soc. Chem. Commun. 1993, 1305-1306. (b) D'Ambrosio, M.; Guerriero, A.; Ripamonti. M; Debitus, C.; Waikedre, J.; Pietra, F. The active centres of agelastatin A, a strongly cytotoxic alkaloid of the coral sea axinellid sponge Agelas dendromorpha, as determined by comparatve bioassays with semi-synthetic derivatives. Helv. Chim. Acta 1996, 79, 727-735.

(28) Mason C. K.; McFarlane, S.; Johnston, P.,G.; Crowe P.; Erwin P. J.; Domostoj M. M.; Campbell F. C.; Manaviazar, S.; Hale, K. J.; El-Tanani, M. Agelastatin A: A novel inhibitor of osteopontinmediated adhesion, invasion, and colony formation. Mol. Cancer Ther. 2008, 7, 548-558.

(29) (a) Hale, K. J.; Domostoj, M. M.; Tocher, D. A.; Irving, E.; Scheinmann, F. Enantiospecific formal total synthesis of the tumor and GSK-3 $\beta$-inhibiting alkaloid (-)-agelastatin A. Org. Lett. 2003, 5, 2927-2930. (b) Domostoj, M. M.; Irving, E.; Scheinmann, F.; Hale K. J. New total synthesis of the marine antitumor alkaloid (-)-agelastatin A. Org. Lett. 2004, 6, 2615-2618. (c) Hale K. J.; Domostoj, M. M.; El-Tanani M.; Campbell F.C.; Mason C. K. Total synthesis and mechanism of action studies on the antitumor alkaloid, (-)-agelastatin A. Strategies and Tactics in Organic Synthesis 2005, 6, 352-394.

(30) Kornegay, J. N.; Bogan, J. R.; Bogan D. J.; Childers, M. K.; Li, J.; Nghiem, P.; Detwiler, D. A.; Larsen, C. A.; Grange R. W.; Bhavaraju-Sanka, R. K.; Tou, S.; Keene, B. P.; Howard, Jr., J. F., Wang, J.; Fan, Z.; Schatzberg, S. J.; Styner, M. A.; Flanigan, K. M.; Xiao, X.; Hoffman, E. P. Canine models of Duchenne muscular dystrophy and their use in therapeutic strategies. Mamm. Genome 2012, $23,85-108$.

(31) Nghiem P. P.; Hoffman, E. P.; Mittal, P.; Brown, K. J.; Schatzberg, S. J.; Ghimbovschi, S.; Wang, Z.; Kornegay, J. N. Sparing of the dystrophin-deficient cranial sartorius muscle is associated with classical and novel hypertrophy pathways in GRMD dogs. $\mathrm{Am} J$ Pathol. 2013, 183, 1411-1424.

(32) López, S. M.; Balog-Alvarez, C.; Canessa, E. H.; Hathout, Y.; Brown, K. J.; Vitha, S.; Bettis, A. K.; Boehler J.; Kornegay J. N.; Nghiem, P. P. Creation and characterization of an immortalized canine myoblast cell line: Myok9. Mamm. Genome 2020, 31, 95-109.

(33) Schneider S. M.; Sridhar, V.; Bettis A. K.; Heath-Barnett, H.; Balog-Alvarez C. J.; Guo L. J.; Johnson, R.; Jaques, S.; Vitha, S.; Glowcwski, A. C.; Kornegay, J. N.; Nghiem, P. P. Glucose metabolism as a pre-clinical biomarker for the golden retriever model of Duchenne muscular dystrophy. Mol. Imaging Biol. 2018, 20, 780-788. 
(-)-Agelastatin A (AA) in 1,2-propanediol (3-deoxy-DLglycerol) elicits a dose-dependent decrease in OPN mRNA expression in canine Duchenne Muscular Dystrophy (DMD) myoblasts at doses ranging from $0.01 \mathrm{nM}-30$ $\mathrm{nM}$. When intraperitoneally administered in the same vehicle to $\mathrm{mdx}$ mice at $2.5 \mathrm{mg} / \mathrm{kg} /$ day for two weeks, and at $1.5 \mathrm{mg} / \mathrm{kg} /$ day twice-weekly for two weeks, (-)-AA brings about a significant decrease in exercise-induced muscle damage through its attenuation of OPN expression. This study confirms that the use of small molecule $\beta$ catenin/OPN downregulatory drugs may beneficially modify phenotype for the treatment of DMD.
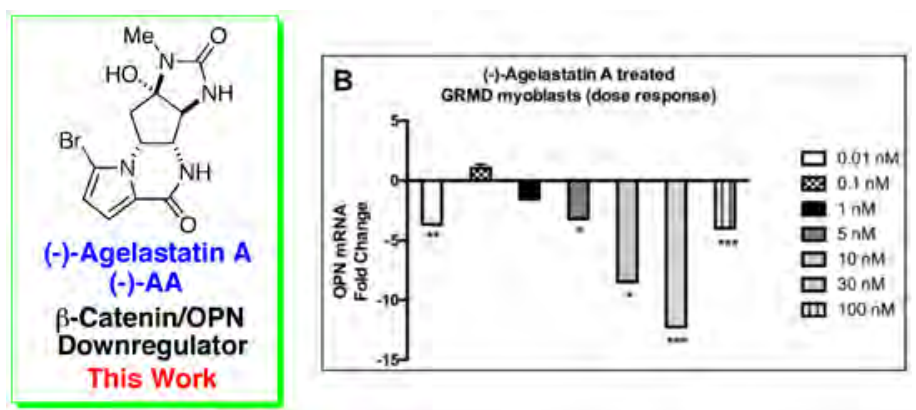


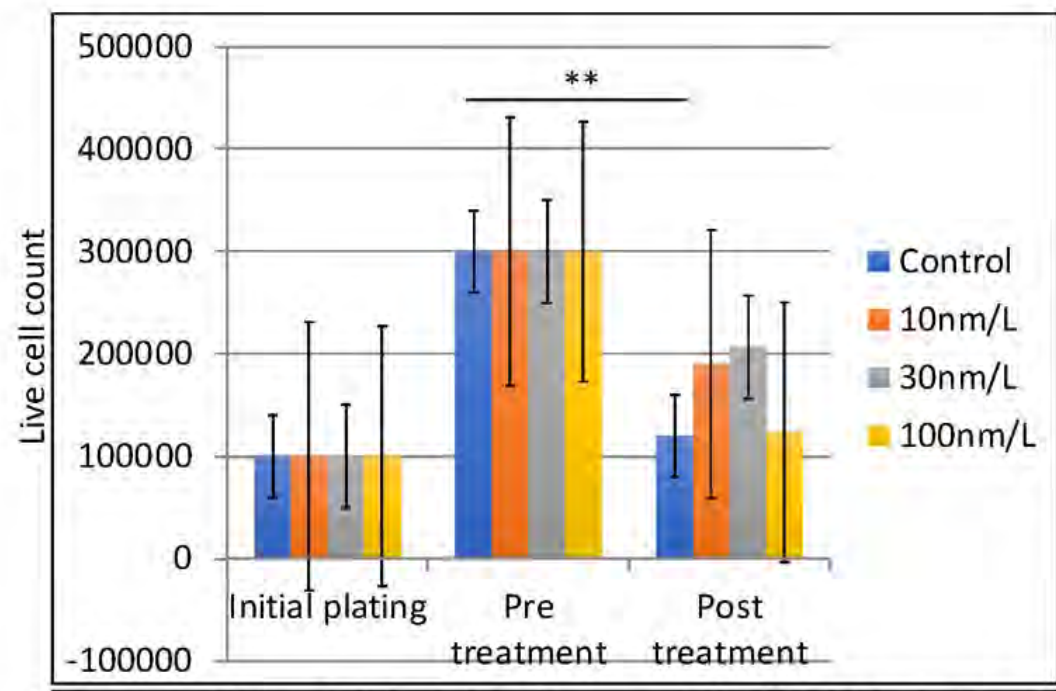

Supplemental Figure 1: (-)-Agelastatin-A resuspended in DMSO led to significant cell death. Control myoblasts were treated with DMSO only while (-)-Agelastatin-A was resuspended in DMSO at various concentrations $(10,30,100, n M / L)$ and subsequently applied to myoblasts. After 48 hours of treatment, there was significant cell death in all treatment groups, including control (DMSO only) treated groups compared to pretreatment ( 0 hours). ${ }^{*}=p<0.01$. 